\title{
IMPLEMENTASI NILAI - NILAI PANCASILA DALAM KEHIDUPAN DI ERA GLOBALISASI
}

\author{
Aini Shifana Savitri ${ }^{1}$, Dinie Anggraeni Dewi ${ }^{2}$ \\ ${ }^{1)}$ Universitas Pendidikan Indonesia \\ ${ }^{2)}$ Universitas Pendidikan Indonesia \\ ainishifana.19@upi.edu \\ dinieanggraenidewi@upi.edu ${ }^{2}$
}

Kata Kunci:
Pancasila, Globalisasi,
Implementasi Pancasila.

\section{Abstrak}

Tujuan dari penelitian ini untuk memberi pemahaman mengenai implementasi nilai-nilai Pancasila di tengah pengaruh globalisasi yang telah dilupakan oleh sebagian masyarakat akibat tergerus arus globalisasi. Dalam menjawab permasalahan. metode penelitian ini menggunakan pendekatan kualitatif melalui metode deskriptif. Hasil penelitian menunjukkan bahwa masyarakat indonesia masih banyak yang tidak menerapkan nilai-nilai pancasila dalam kehidupan seharihari maupun kehidupan bermasyarakat di era globalisasi ini, bahkan sebagian dari mereka sudah melupakan nilai-nilai yang terkandung dalam Pancasila sebagai pandangan hidup bangsa Indonesia. Pancasila adalah suatu sistem nilai yang merupakan satu kesatuan dan tidak dapat terpisahkan. Dengan demikian, Pancasila dapat menjadi kekuatan moral besar apabila keseluruhan nilai Pancasila dijadikan landasan moril serta diterapkan dalam kehidupan berbangsa dan bernegara.
Keyword:

Pancasila, Globalization, Implementation of Pancasila.
The purpose of this study is to provide an understanding of the implementation of Pancasila values in the midst of the influence of globalization that has been forgotten by some people due to the erosion of globalization. In answering the problem. This research method uses a qualitative approach through descriptive methods. The results show that many Indonesian people do not apply the values of Pancasila in their daily life and social life in this era of globalization, even some of them have forgotten the values contained in Pancasila as the way of life of the Indonesian people. Pancasila is a value system which is one unit and cannot be separated. Thus, Pancasila can become a great moral force if the overall values of Pancasila are used as a moral foundation and are applied in the life of the nation and state. @ Inventa: Jurnal Pendidikan Sekolah Dasar Copy Right

\section{Pendahuluan}

Pancasila sebagai dasar Negara sangat berperan penting bagi kehidupan bangsa dalam menyikapi zaman yang terus berkembang karena nilai-nilai yang terkandung dalam pancasila dapat dikembangkan beriringan dengan kehidupan bangsa Indonesia. Masyarakat disini perlu memahami Pancasila 
untuk diimplementasikan dalam kehidupan sehari-hari.

Pancasila sebagai suatu dasar filsafat negara, maka sila- sila Pancasila merupakan suatu sistem nilai, oleh karena itu sila-sila Pancasila itu pada hakikatnya merupakan suatu kesatuan (Kaelan dikutip dalam Asmaroini, 2017). Pada zaman modern ini, banyak pengaruh negatif terhadap suatu Negara akibat dari globalisasi, salah satunya melunturnya nilai - nilai luhur yang terdapat di Indonesia. Dengan segala pengaruh negatif yang masuk, salah satunya adalah pengaruh budaya luar yang bertentangan dengan nilai - nilai Pancasila. Banyak warga Negara yang kurang memahami Pancasila bahkan melupakan Pancasila dalam kehidupannya, dikarenakan pengaruh negatif dari globalisasi.

Masalah yang muncul atauancaman bagi negara Indonesia dari pengaruh globaliasi terhadap tatanan negara merupakan suatu ancaman yang besar dan tidak bisa dianggap remeh. Dengan mudah pengaruh negatif dari luar yang masuk ke Indonesia, secara perlahan berdampak terhadap karakter bangsa.

Permasalahan ini berdampak pada kehidupan masyarakat yang melupakan jati diri bangsanya yang menjunjung tinggi nilai - nilai Pancasila sebagai bentuk warga negara yang baik. Pancasila adalah suatu moral, suatu pergaulan hidup antara manusia Indonesia yang satu dengan manusia Indonesia yang lainnya tanpa memandang tingkatannya, tanpa memandang keturunannya, tanpa memandang status sosialnya (Aulia dalam seminar nasional: aktualisasi nilai-nilai Pancasila di era reformasi).

Globalisai dapat membawa perubahan perubahan dalam tatanan dunia yang berpengaruh langsung terhadap suatu negara. Perubahan ini lah yang dirasakan langsung oleh masyarakat Indonesia baik itu perubahan positif maupun perubahan negatif. Hal ini menjadi tantangan besar bagi bangsa Indonesia. Oleh karena itu, perlu masyarakat memiliki kemampuan dalam menghadapi tantangan tersebut yang akan melanda kehidupan nasional, ekonomi, politik, sosial dan budaya melalui pengamalan dan penghayatan nilainilai Pancasila. Dengan menerapkan nilai-nilai Pancasila di dalam kehidupan sehari-hari, masyarakat Indonesia akan lebih terbentengi dan menjaga moral bangsa dengan menghayati dan mengamalkannya agar tetap menjadi pedoman hidup bangsa.

Seperti yang diketahui, kini banyak generasi muda yang moralnya sudah rusak akibat perngaruh globalisasi. Seperti pengaruh teknologi yang semakin canggih, teman bergaul, narkoba, minuman keras, dan sebagainya. Masalah - masalah tersebut perlu diperhatikan karena dapat berdampak besar pada kemajuan dan perkembangan negara.

Hal ini diharapkan bisa dibenahi dengan penerapan nilai - nilai Pancasila agar generasi yang akan datang memiliki akhlak 
dan moral yang baik. Pancasila sangat diperlukan dalam era globalisasi ini karena menjadi pembatas agar kita dapat memilih budaya yang sesuai dengan budaya bangsa Indonesia dan bermanfaat bagi bangsa dan negara. Hal tersebut perlu didukung dengan kesadaran warga negara Indonesia dalam menyikapi era globalisasi ini agar pengaruh yang masuk dapat bermanfaat dan membuat bangsa Indonesia semakin maju dan berkembang.

\section{Metode}

Metode dalam penelitian ini menggunakan pendekatan kualitatif dengan metode deskriptif analisis untuk menjawab permasalahan yang diajukan. Peneliti mengkaji data - data melalui studi literatur dengan mengumpulkan data dari sumber referensi seperti jurnal, buku dan artikel melalui sumber digital.

\section{Hasil dan Pembahasan}

Nama Pancasila terdiri dari dua kata sansekerta, yaitu "pancae yang artinya lima, dan "sila' yang artinya prinsip atau asas. Jadi, Pancasila adalah prinsip dan pedoman hidup berbangsa dan bernegara bagi seluruh rakyat Indonesia. Pancasila memiliki serangkaian nilai yakni ketuhanan, kemanusiaan, persatuan, keakyatan, dan keadilan yang digunakan oleh masyarakat dalam menjalani kehidupannya.
Pancasila bukan hanya rumusan yang terbentuk secara instan tanpa memiliki sumber yang kuat, melainkan pancasila adalah rumusan dasar negara yang bersumber pada nilai - nilai moral kepribadian bangsa Indonesia, baik nilai agama, sosial dan budaya yang telah melekat bersamaan dengan esksistensi bangsa Indonesia (Aulia dalam seminar nasional: aktualisasi nilai - nilai Pancasila di era reformasi).

Sehingga dapat disimpulkan bahwa Pancasila merupakan dasar negara Republik Indonesia yang digunakan dalam kehidupan bangsa Indonesia di segala bidang kehidupan yang di dalam nya mengandung tatanan kehidupan bangsa Indonesia. Pancasila menjadi ideologi dasar negara Indonesia guna menjadikan warga negara yang baik. Dalam membentuk warga negara yang baik harus sesuai dengan nilai - nilaipancasila. Pancasila sebagai acuan atau pedoman hidup bangsa Indonesia untuk mengatur perilaku warga negara menjadiwarga negara yang baik (good citizen). Mengikui zaman yang semakin modern atau zaman globalisasi banyak pengaruh dari luar yang melunturkan nilai nilai luhur pancasila. Kelangsungan hidup negara dan bangsa Indonesia di era globalisasi saat ini, mengharuskan kita untuk melestarikan nilai - nilai pancasila.

\section{Pancasila Sebagai Ideologi Negara}

Ideologi memiliki peran penting dalam memelihara persatuan negara. Istilah ideologi berasal dari kata "idea" 
yang artinya gagasan, konsep, dan "logos" yang artinya ilmu. Kata idea sendiri berasal dari bahasa Yunani “eidos” yang berarti bentuk. Selanjutnya ada kata "Idein" yang berarti melihat. Sehingga dengan hal itu, secara harfiah ideologi berarti ilmu, pengertian-pengertian dasar, cita-cita yang bersifat tetap yang harus dicapai, sehingga cita-cita yang bersifat tetap itu yang harus dicapai, sekaligus merupakan dasar, pandangan atau faham (Kaelan dalam Asmaroini, 2017).

Sebagai ideologi, Pancasila sebagai persatuan budaya yang berkembang secara alami dalam kehidupan/bukan dengan paksaan, artinya pancasila sudah mendarah daging dalam kehidupan sehari - haribangsa Indonesia. kekuatan ideologi tergantung pada kualitas tiga dimensi yang dimiliki oleh ideologi itu (Alfian dikutip dalam Asatawa, 2017) yaitu :

1) Dimensi Realita,

Nilai-nilai dasar yang ada pada ideologi itu mencerminkan suatu kenyataan dalam kehidupan masyarakat. Nilai dasar ideologi tersebut paling tidak telah mencerminkan kenyataan masyarakat pada kelahirannya.
2) Dimensi Iidalisme,

Nilai dasar yang mengandung kualitas ideologi dapat memberikan harapan masyarakat untuk masa depan yang lebih baik melalui pengalaman dalam kehidupan sehari - hari.

3) Dimensi Fleksibelitas atau dimensi pengembangan,

Kemampuan ideologi dalam mempengaruhi dan menyesuaikan diri dengan perkembangan masyarakat. Mempengaruhi berarti ikut berpartisipasi dalam proses perkembangan zaman dengan tidak menghilangkan jati diri ideologi tersebut yang tercermin dalam nilai dasar.

Sebagai ideologi, Pancasila bukan hanya hasil dari pemikiran seseorang atau kelompok orang, namun pancasila mengangkat nilai adat istiadat, nilai kebudayaan, serta nilai religious yang sudah menjadi pandangan hidup bangsa Indonesia sebelum membentuk negara.

Pancasila sebagai ideologi nasional mengatasi faham perseorangan, golongan, suku, bangsa serta agama. Maka semboyan "Bhineka Tunggal Ika $^{\text {ee }}$ diterapkan bagi seluruh masyarakat Indonesia dalam kesatuan yang utuh. Pancasila sebagai ideologi 
nasional memiliki upaya untuk menempatkan kepentingan bangsa dan Negara dalam kedudukan utaam di atas kepentingan yang lainnya (Asmaroini, 2017).

\section{Nilai - Nilai yang Terkandung dalam}

\section{Pancasila}

Nilai-nilai yang terkandung dalam Pancasila akan mengajarkan cara berfikir dan bertindak yang sesuai dengan ideologi negara (Damanhuri, dkk 2016). Terdapat nilai - nilai yang terkandung dalam lima sila pancasila, antara lain :

\section{a) Sila pertama, Ketuhanan yang Maha} Esa

Dalam sila pertama, nilai yang terkandung adalah kita sebagai manusia itu diciptakan oleh tuhan dan wajib menjalankan perintah-Nya serta menjauhi segala larangan-Nya. Seluruh warga Negara Indonesia berkah memeluk agama yang dipercaya masing - masing dan wajib menjalani apa yang diperintahkan oleh agamanya. Dalam sila ini juga, masyarakat bisa membangun toleransi di antara umat beragama, serta menghargai seluruh makhluk ciptaan Tuhan, tidak hanya manusia, seperti hewan, tumbuhan. Hal ini juga akan berguna bagi lingkungan yang terjaga karena manusianya yang memiliki rasa syukur atas kepercayaannya kepada penciptanya. b) Sila Kedua, Kemanusiaan yang Adil dan Beradab

Dalam sila kedua ini, nilai yang terkandung bahwa sebagai manusiakita mempunyai derajat yang sama sesama manusia di lingkungan masyarakat dan di mata hukum. Pancasila mengandung nilai humanis (Sitorus, 2016). Masyarakat Indonesia akan lebih berdamai apabila selalu menerapkan sila kedua ini dalam kehidupannya, karena sila ini menekankan pada aspek sosial yang memiliki prinsip mencintai sesama manusia dan manusia memiliki derajat yang sama dimanapun, tanpa melihat agamanya, ras, suku, golongan.

\section{c) Sila Ketiga, Persatuan Indonesia}

Sila ketiga ini mengandung nilai nilai persatuan. Makna persatuan disini bahwa Indonesia itu tidak bisa terpecahkan. Seperti yang kita tahu, Indonesia memiliki banyak pulau, yang artinya jutaan manusia tinggal dan hidup di Indonesia. apabila persatuan tidak ditekankan dalam kehidupan, maka tidak akan terjadi perdamaian di Negara Indonesia. dalam hal ini, perlu dikembangkan rasa cinta tanah air, rasa cinta pada bangsa nya dan bhineka tunggal ika. 
d) Sila Keempat, Kerakyatan yang $\begin{array}{lrr}\text { Dipimpin } & \text { Oleh } & \text { Hikmat } \\ \text { Kebijaksanaan } & & \text { dalam }\end{array}$ Permusyawaratan Perwakilan

Sila keempat ini mengandung makna yang menjelaskan tentang adanya kebersamaan atau kerja sama dalam mengambil suatu keputusan dan cara menanganinya serta adanya kejujuran. Artinya, para pemimpin di Indonesia perlu memiliki kebijaksanaan dalam mengambil keputusan untuk kebaikan masyarakat. Terkandung di dalamnya prinsip asasi Kerakyatan; Musyawarah mufakat; Demokrasi;

e) Sila Kelima, Keadilan Sosial Bagi Seluruh Rakyat Indonesia

Dalam sila kelima ini/disebutkan kata adil maka kata tersebut dilihat oleh manusia selaku individu. Sesuatu hal dikatakan baik apabila sudah sesuai dengan prinsip keadilan masyarakat (Amri, 2018).

Dari nilai kelima pancasila ini, berkembang perbuatan i yang mencerminkan sikap kekeluargaan juga gotong royong. Dengan demikian, dikembangkanlah sikap adil antar sesama, menjaga keseimbangan antara hak dan kewajiban serta menghormati hak - hak orang lain (Amri, 2018).

Maka dari itu, Makna dalam sila kelima ini sangat besar, yakni menyangkut kehidupan warga Negara. Kemakmuran seluruh rakyat dan seluruh kekayaan menjadi kemakmuran bersama dengan membantu yang lemah dan melindunginya

\section{Kondisi Masyarakat Indonesia dalam} Menerapkan Nilai - Nilai Pancasila

Kondisi bangsa Indonesia saat ini dapat dilihat dari pola perilaku dan kepribadian masyarakat yaitu tercermin pada tingkah laku dalam kehidupan sehari - hari. Kehidupan masyarakat yang cukup serius dari masyarakat akibat kemiskinan dan pembodohan oleh sistemkolonialisme, imperialisme, dan kapitalisme. Masyarakat Indonesia memiliki peluang untuk mencapai kemakmuran apabila menerapkan sistem humanis dan adil. Dengan demikian, Pancasila ada untuk menggapai kehidupan masyarakat yang adil dan makmur. Adapun perilaku masyarakat yang tidak sesuai dengan nilai - nilai pancasila sebagai berikut:

1) Sila pertama

Kini, banyak dijumpai generasi muda yang tidak beriman kepada tuhan yang maha esa, mereka tidak memedulikan kepercayaannya, seperti meninggalkan ibadah, melanggar peraturan agama, dan sebagainya.

2) Sila kedua

Saat ini sering kita temui generasi muda Indonesia yang tidak 
memanusiakan orang lain sebagaimana mestinya. Mereka lebih mementingkan kebahagiaan atau kepuasan dari dirinya tanpa memikirkan hak orang lain. Seperti pembunuhan, pemerkosaan, pembegalan, dan sebagainya.

3) Sila ketiga

Melunturnya rasa persatuan dan kesatuan yang terjadi kini di Indonesia menyebabkan berbagai pertengkaran dan keributan yang terjadi di lingkungan masyarakat karena tidak menerapkan sikap persatuan, seperti tawuran, bentrok antar warga atau antar daerah satu dengan daerah lain, dan sebagainya.

4) Sila keempat

Masalah yang terjadi saat ini di Indonesia terkait dengan demokrasi yaitu money politic yang masih dijumpai saat pemilihan pemimpin.

5) Sila kelima

Mengenai keadilan, banyak permasalahan keadilan yang dilakukan oleh masyarakat terutama orang yang memiliki kepentingan pribadi. Seperti dalam dunia hukum, masih ada orang yang tidak di pandang secara merata misalnya orang yang tidak bersalah namun ia tidak memiliki kekurangan dalam hal keuangan, sulit untuk ia membela diri nya.

\section{Globalisasi}

Kata globalisasi diambil dari global yang artinya atau maknanya universal. Globalisasi adalah proses sosial yang berakibat pembatasan geografis pada keadaan sosial budaya menjadi kurang penting yang terjelma di dalam kesadaran seseorang. (Waters dikutip dalam Nurhaidah, 2015), Sedangkan menurut (Lyman dikutip dalam Nurhaidah, 2015), globalisasi adalah pertumbuhan yang sangat cepat yang saling ketergantungan dan hubungan antar negara di dunia dalam hal perdagangan dan keuangan. Sehingga dapat disimpulkan bahwa, Globalisasi adalah fenomena dalam kehidupan manusia yang bergerak dan berkembang secara terus menerus.

Globalisasi merupakan suatu gejala meleburnya kultur dunia akibat dari sosio-cultural antar bangsa yang mendunia. Sehingga hubungan antar bangsa pun menjadi dekat. Globalisasi ini sering dikaitkan dengan perkembangan teknologi informasi, perkembangan dunia ekonomi, pemanasan global, dan sebagainya.

Sebagai masyarakat, kita tidak dapat menghentikan arus globalisasi karena seiring berjalannya globalisasi ini sangat erat dengan berkembangnya ilmu pengetahuan dan teknologi. Dampak yang ditimbulkan pun tidak dapat dihindarkan. 
Bagi masyarakat, globalisasi tidak hanya berdampak positif, namun dampak negatif pun turut dirasakan oleh masyarakat. Menurut (Suparlan dikutip dalam Asmaroini, 2017), dampak positif dan negatif dari globalisasi antara lain:

\section{Dampak positif globalisasi}

1) Semangat berkompetisi, karena melihat arus globalisasi yang terus berkembang, masyarakat dituntut untuk mampu bersaing tidak hanya di dalam Negara, namun di dunia internasional. Sehingga timbul kemandirian serta kemajuan pribadi yang ikut membantu memajukan negarajuga.

2) Mempermudah Kenyamanan hidup, dengan kemajuannya di bidang teknologi informasi dan transportasi telah memberti kemudahan dalam menjalani kehidupan masyarakat.

3) Tumbuhnya sikap toleransi dan solidaritas antar manusia, seiring berkembangnya teknologi informasi, masyarakat lebih mudah mengakses segala informasi dari dalam negeri maupun luar negeri. Informasi kemanusiaan mengenai keprihatinan dan penderitaan sekelompok manusia di suatu negara, memotivasi pemerintah negara lain untuk membantu meringankan penderitaan sesamanya. Akhirnya, timbul sikap toleransi dan solidaritasantar manusia karena bantuan dari teknologi yang mempersatukan manusia antar negara.

4) Globalisasi memberi tawaran baru berupa akses ilmu pengetahuan seluas - luasnya. Hal ini bermanfaat bagi generasi yang akan datang untuk lebih mudah dalam mencari ilmu yang berdampak pada kemajuan Negara.

\section{Dampak Negatif Globalisasi}

1) Pergeseran nilai, karena sesuatu yang baru dari luar secara tidak otomatis diintergrasikan ke dalam kondisi individu atau masyarakat yang menerimanya.

2) Pertentangan nilai, denganmasuknya nilai - nilai baru yang tidak sejalan atau tidak sesuai dengan nilai luhur dari pandangan hidup masyarakat Indonesia menyebabkan lunturnya nilailuhur bangsa.

3) Perubahan gaya hidup (life style), perubahan gaya hidup ke arah negatif sangat merugikan negara seperti hedonis, yang selalu menghambur - hamburkan kekayaan dan konsumtif yakni membeli barang tidak sesuai dengan kebutuhannya serta individualis. 


\section{Tantangan Globalisasi Terhadap}

Nilai-Nilai Pancasila

Tantangan yang harus dihadapi masyarakat di era globalisasi adalah munculnya paham - paham yang bertentangan dan tidak sesuai dengan ideologi pancasila. Dalam memfilter hal tersebut, dipengaruhi oleh pemahaman dan kesadaran terhadap nilai - nilai pancasila yang ada di dalam diri masyarakat. Berikut tantangan globalisasi berdasarkan nilai pancasila:

1) Nilai kesatu

Pancasila merupakan kristalisasi nilai-nilai budaya yang berkembang dalam kehidupan beragama di masyarakat (Mangunsong \& Fitria, 2019). Tantangan globalisasi terhadap nilai kesatu pancasila dapat dilihat dan dicermati melalui fenomena agama KTP yang diperlihatkan oleh sebagian masyarakat. Tantangan aktualisasi nilai spiritualitas tersebut terkait adanya perspektif sebagian anak bangsa yang melihat alternatif ideologi agama bagi negara (Silitoga, 2020).

Tantangan lain yakni munculnya nilai komunisme/sosialisme, sekularisme, teokrasi, dan liberalisme yang tidak sesuai dengan nilai yang terkandung dalam sila kesatu. Sementara itu, dalam
Komunisme/sosialisme sudut pandang materialisme menjadi dasar pemahaman dan terdapat ciri ateis karena manusia ditentukan oleh diri sendiri dan bukan terikat oleh kausalitas dengan Tuhan (Setijo, 2006). Sekularisme adalah paham yang memisahkan antara agama dan negara (Kaelan, 2004). Teokrasi adalah paham yang memandang agama dan negara tidak bisa dipisahkan (Kaelan, 2004). Liberalisme merupakan paham yang berkembang dari akar rasionalisme serta individualism yang meletakkan nilai dan kebebasan individu sebagai nilai tertinggi dalam kehidupan bermasyarakat dan bernegara (Kaelan, 2004).

2) Nilai Kedua

Tantangan nilai kedua dapat dicermati dari perilaku anak bangsa. Di era globalisasi ini yang sangat terbuka dalam informasi diartikan dengan kebebasan tanpa batas, sehingga terjadi perilaku perundungan, persekusi, dan menghujat orang. Tantangan yang perlu diperhatikan juga terkait sila kedua ini yaitu, pada dinamika terorisme yaitu adanya sebagian anggota masyarakat yang terjebak dalam pola pikir dan tindak radikalisme (Silitoga, 2020). 
Peledakan bom dan bom bunuh diri yang terjadi di Indonesia menjadi bukti dari pengabaian nilai - nilai kemanusiaan dalam sila kedua pancasila ini. Pelaku teror yang terlibat telah menagabaikan nilai - nilai kemanusiaan karena operasinya merugikan hak kemanusiaan dan membuat rasa takut.

3) Sila Ketiga

Tantangan dalam mengaktualisasikan nilai sila ketiga Pancasila pada masyarakat, dapat dicermati dari munculnya hegemoni komunitas, dan pesimisme. Sementara itu hegemoni sektarian/ komunitas adalah paham yang didasarkan pada pemikiran kelompok tertentu dengan label sebagai komunitas mayoritas memiliki Keeksklusifan (Silitoga, 2020).

\section{4) Sila Keempat}

Dalam sila keempat ini terkandung nilai penghormatan terhadap demokrasi dan tanggung jawab kepada Tuhan Yang Maha Esa, memperkokoh persatuan dan kesatuan negara, serta mewujudkan kesejahteraan bersama. praktik politik identitas, politik irasional, dan politik uang menjadi tantangan bagi masyarakat Indonesia.

\section{5) Sila Kelima}

Tantangan masyarakat yang berkaitan dengan nilai dalam sila kelima ini adalah muncul paham kapitalisme, kapitalisme, hedonisme, dan individualism. Padahal sila kelima ini bertujuan untuk mewujudkan keadilan dalam kehidupan berbangsa dan bernegara. Bahkan sebagian masyarakat terkesan memaksakan diri untuk ikut dalam hidup yang serba mewah tersebut sehingga menimbulkan masalah baru yakni korupsi. Dengan demikian, kejahatan korupsi telah mengakibatkan kehancuran perekonomian bangsa (Bunga et al, 2019). Selain itu, masyarakat banyak menderita karena perilaku korupsi antara lain kehilangan lahan, pekerjaan, dan tanah kelahiran (Muryanti, 2018). Faktor materialism berpengaruh dan dapat terus-menerus mengikis nilai-nilai luhur masyarakat (Juneman et al., 2012).

\section{Implementasi Pancasila Dalam Menghadapi Tantangan Globalisasi}

Pada kenyataannya, kita harus mengakui bahwa pancasila belum mendapatkan kedudukan yang tepat di hati bangsa Indonesia. pemahaman nilai nilai pancasila belum benar - benar dipahami atau dihayati, terbukti dari 
banyaknya implementasi budaya asing yang tidak sesuai dengan budaya Indonesia. Oleh karena itu, pancasila perlu ditanamkan kembali khususnya bagi generasi muda dalam proses mengembangkan dirinya yang akan melakukan pembangunan Indonesia di masa yang akan datang.

1) Sebagai pribadi, seseorang dapat bersikap sebagai hamba tuhan sesuai dengan agama dan kepercayaan masing - masing yang mampu bersyukur dan menghargai ciptaan tuhan yang lainnya, sehingga tercipta keadilan di dalam kehidupannya.

2) Sebagai anggota keluarga dan masyarakat, seseorang dapat menempatkan dirinya dengan benar sesuai dengan fungsi dan tugasnya. Ia harus paham dan mampu menempatkan hak dan kewajiban dalam kebersamaanhidup.

3) Sebagai warga negara, seseorang harus mampu memahami hak dan kewajiban sesuai dengaan peraturan yang berlaku, mampu membawa dirinya secara tepat dalam hubungan dengan warga lain.

\section{Kesimpulan}

Pancasila sebagai dasar negara dan pandangan hidup bangsa Indonesia dijadikan sebagai dasar berperilaku seseorang dalam membangun negara. Pancasila bukan hanya rumusan, melainkan lebih dari itu, pancasila perlu diupayakan di berbagai bidang dalam kehidupan seluruh masyarakat.

Arus globalisasi tidak dapat dihentikan, dengan segala dampak yang ditimbulkan seharusnya memberikan pengaruh positif. Namun, pengaruh globalisasi ternyata banyak menimbulkan pengaruh yang negative bagi kebudayaan bangsa Indonesia. Oleh karena itu, pembudayaan nilai - nilai Pancasila perlu diupayakan. Kita harus bersikap selektif dalam mengikuti perkembangan globalisasi agar nilai - nilai luhur bangsa Indonesia tetap terjaga.

Solusi dari segala permasalahan yang terjadi di Indonesia saat ini terkait pengamalan pancasila adalah Indonesia mempunyai Ideologi Pancasila diharapkan mampu untuk membawa bangsa Indonesia menjadi bangsa yang lebih bagus dari sekarang. Ideologi juga diharapkan mampu untuk membangkitkan kesadaran bangsa. Setiap pengambilan keputusan harus berdasarkan ideologi negara Indonesia yaitu Pancasila. Supaya dalam pengambilan keputusan tidak keluar dari aturan dan kaidah negara Indonesia.

\section{Daftar Pustaka}

Amri, S. R. (2018). Pancasila Sebagai Sistem Etika. Jurnal Voice Of Midwifery, 8(1), 760-768.

Asatawa, I. P. A. (2017). Pancasila Sebagai Ideologi dalam Berbagai Bidang 
Kehidupan Bermasyarakat, Berbangsa dan Bernegara. Makalah Fakultas Peternakan, Universitas Udayana.

Asmaroini, A. P. (2017). Menjaga Eksistensi Pancasila dan Penerapannya bagi Masyarakat di Era Globalisasi. Jurnal Pancasila dan Kewarganegaraan, 1(2), 50- 64.

Asmaroini, A. P. (2016). Implementasi Nilai Nilai Pancasila Bagi Siswa di Era Globalisasi. CITIZENSHIP: Jurnal Pancasila dan Kewarganegaraan, 4(2), 440-450.

Aulia, S. S. Pancasila di Arus Globalisasi dalam Memperkuat Reformasi Moral Indonesia. Artikel Seminar Nasional : Aktualisasi Nilai - Nilai Pancasila di Era Reformasi. FKIP Universitas Ahmad Dahlan

Bunga, M, et al. (2019). Urgensi Peran Serta Masyarakat dalam Upaya Pencegahan dan Pemberantasan Tindak Pidana Korupsi. Jurnal Law Reform, 15(1), 8597.

Damanhuri, et al. (2016). Implementasi Nilai - Nilai Pancasila Sebagai Upaya Pembangunan Karakter Bangsa. Untirta Civic Education Journal, 1(2), 185-198.

Mangunsong, N., \& Fitria, V. (2019). Pancasila dan Toleransi pada Tradisi Keagamaan Masyarakat Yogyakarta. Jurnal Civics: Media Kajian Kewarganegaraan. 16(1), 89-97.
Muryanti. (2018). Tindakan Korupsi sebagai Tindakan Imoral dalam Perspektif Fungsional (Kajian Film Korupsi dan Kita: Rumah Perkara). Jurnal Komunikasi Profetik, 11(2), 32-45.

Nurhaidah. dan Musa, M. I. (2015). Dampak Pengaruh Globalisasi Bagi Kehidupan Bangsa Indonesia. Jurnal Pesona Dasar, $3(2), 1-14$.

Juneman, Meinarno, E. A., \& Rahardjo, W. (2012). Symbolic Meaning of Money, Self-Esteem, and Identification with Pancasila Values. Procedia - Social and Behavioral Sciences, 65, 106-115.

Kaelan. (2004). Pendidikan Pancasila (8th ed.). Paradigma.

Setijo, P. (2006). Pendidikan Pancasila: Perspektif Sejarah Perjuangan Bangsa, dilengkapi dengan Undang - Undang Dasar Hasil Amandemen. Gramedia.

Silitoga, T. B. (2020). Tantangan Globalisasi, Peran Negara, dan Implikasinya Terhadap Aktualisasi Nilai-Nilai Ideologi Negara. Jurnal Civics: Media Kajian Kewarganegaraan, 17(1), 16-28.

Sitorus, J. H. E. (2016). Pancasila-based social responsibility accounting. Procedia - Social and Behavioral Sciences, 219, 700-709.

\section{.}

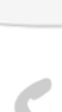




\begin{tabular}{|l|l|l|}
\hline \multicolumn{2}{|c|}{$\begin{array}{c}\text { Identitas Penulis } \\
\text { Corresponding author }\end{array}$} \\
\hline Nama Lengkap & $:$ & Aini Shifana Savitri \\
\hline Afiliasi / Institusi & $:$ & Universitas Pendidikan Indonesia \\
\hline Email & $:$ & Ainishifana.19@upi.edu \\
\hline No HP / WhatsApp & $:$ & 085773200251 \\
\hline
\end{tabular}

- Identitas penulis Wajib di isi oleh salah satu penanggung jawab pengirim artikel 